\title{
Tolerance to white spot syndrome virus (WSSV) in the freshwater prawn Macrobrachium rosenbergii is associated with low VP28 envelope protein expression
}

\author{
K. Yoganandhan ${ }^{1,2, \mp}$, A. S. Sahul Hameed ${ }^{3, *}$ \\ ${ }^{1}$ Centex Shrimp, Faculty of Science, Chalermprakiat Building, Mahidol University, 272 Rama VI Road, Bangkok 10400, Thailand \\ ${ }^{2}$ National Center for Genetic Engineering and Biotechnology (BIOTEC), National Science and Technology Development Agency, \\ Thailand Science Park, 111 Paholyothin Road, Klong 1, Klongluang, Pathumthani 12120, Thailand \\ ${ }^{3}$ Aquaculture Division, Department of Zoology, C. Abdul Hakeem College, Melvisharam 632509, Hakeem Nagar, Vellore Dt., \\ Tamil Nadu, India
}

\begin{abstract}
The freshwater prawn Macrobrachium rosenbergii was experimentally infected with white spot syndrome virus (WSSV) by intramuscular injection. Infection was confirmed by positive, single-step, WSSV polymerase chain reaction (PCR) assays targeting the VP28 gene from Day 2 up to Day 90 post injection (p.i.). Although no mortality of WSSV-infected prawns was observed, bioassays with the black tiger shrimp Penaeus monodon using hemolymph from Day 90 PCR-positive prawns resulted in white spot disease (WSD). Transcriptional analysis of the VP28 gene of WSSV by reverse transcriptase (RT)-PCR assays and Western blot assays revealed transient expression of the VP28specific transcript in DNase-treated total RNA from hemolymph, gills, head soft tissue and eyestalks at $2 \mathrm{~d}$ p.i. By $3 \mathrm{~d}$ p.i., the VP28 transcript could no longer be detected in eyestalks and hemolymph but was still lightly detectable in head soft tissue and gills. It became undetectable there from $5 \mathrm{~d}$ p.i. onwards, despite the undiminished presence of the virus shown by single-step PCR targeting of the VP28 gene. VP28 was not detected by the less sensitive Western blot in hemolymph at any time during the study period, but it was detectable in all other tested tissues from Days 2 to 4 p.i. Our results demonstrated that $M$. rosenbergii is tolerant to a relatively constant level of persistent WSSV infection characterized by a low expression of VP28 and, possibly, other virion proteins. Despite this, $M$. rosenbergii can carry a level of infectious WSSV sufficient to represent a feasible threat to cultivated penaeid shrimp such as $P$. monodon. It remains to be seen whether a very low virion protein expression relative to the viral copy number may constitute a general decapod characteristic for persistent viral infections that produce no signs of disease.
\end{abstract}

KEY WORDS: Macrobrachium rosenbergii $\cdot$ WSSV $\cdot$ VP28 gene $\cdot$ Transcriptional analysis

\section{INTRODUCTION}

White spot disease (WSD) caused by white spot syndrome virus (WSSV) continues to be a major problem for the shrimp culture industry worldwide. WSSV is enveloped and has a bacilliform morphology measuring $266 \pm 13 \mathrm{~nm}$ in length and $112 \pm 7 \mathrm{~nm}$ in width. The nucleocapsid measures $420 \pm 18 \mathrm{~nm}$ in length and $68 \pm 5 \mathrm{~nm}$ in width (Wongteerasupaya et al. 1995, Sahul Hameed et al. 1998). The doublestranded viral DNA is $305 \mathrm{~kb}$ with 181 open reading frames (van Hulten et al. 2001a, Yang et al. 2001).
Recent studies have led to the placement of WSSV into a new genus, Whispvirus, and a new family, Nimaviridae (van Hulten et al. 2001a, Mayo 2002). Since 1993, WSSV has been reported to cause massive disease outbreaks which have resulted in high mortalities not only in penaeid shrimps, but also in a wide range of hosts including more than 40 species of crabs, copepods and other arthropods (Cai et al. 1995, Wang et al. 1998). It naturally infects all the major species of cultivated penaeid shrimp (Wongteerasupaya et al. 1995, Flegel 1997, Loh et al. 1997, Nunan et al. 1998, Sahul Hameed et al. 1998). 
Both natural and experimental infections have been reported in caridean shrimp (Exopalaemon orientalis and Macrobrachium rosenbergii) (Chang et al. 1998, Peng et al. 1998a, Wang et al. 1998), crayfish (Cambarus clarki and Pacifastacus leniusculus) (Jiravanichpaisal et al. 2001, Huang et al. 2002), wild crabs (Calappa lophos, Portunus sanguinolentus, Portunas pelagicus, Charybdis sp., Helice tridens and Scylla serrata) (Chang et al. 1998, Kanchanaphum et al. 1998, Chen et al. 2000, Corbel et al. 2001), wild lobsters (Scyllarus arctus and Panulirus sp.) (Chang et al. 1998), planktonic copepods and pupae of an ephydrid insect (Wang et al. 1998). Experimental infections of WSSV in freshwater crabs (Paratelphusa hydrodomous and $P$. pulvinata), Artemia and 20 species of marine crabs have been conducted (Sahul Hameed et al. 2001, 2002, 2003). Studies on WSSV-pathogenicity for juveniles and adults of $M$. idella, $M$. lamerrae and $M$. rosenbergii indicated that $M$. idella and $M$. lamerrae were susceptible to WSSV whereas M. rosenbergii was not (Sahul Hameed et al. 2000). However, the larvae of M. rosenbergii were reported to be susceptible (Peng et al. 1998a). Shrimp, like other invertebrates, are considered to lack a true adaptive immune system (Bachère et al. 1995) and to depend instead on various innate immune responses to invading pathogens. However, knowledge of shrimp defenses against viral pathogens lags far behind that of defenses against bacteria and fungi (Flegel 2001) and researchers have only recently begun to address this topic, especially at the molecular level.

In the present study we describe results from reverse transcriptase (RT)-PCR and Western blot analyses used to monitor the expression of the WSSV structural protein VP28 in Macrobrachium rosenbergii after challenge with WSSV by injection.

\section{MATERIALS AND METHODS}

Experimental animals. Macrobrachium rosenbergii individuals (15 to $20 \mathrm{~g}$ body weight) were collected from a hatchery and farm located near Chennai, India. The prawns were fed with commercial pellet feed (CP feed) and acclimatized in 1001 aquaria at room temperature $\left(27\right.$ to $\left.30^{\circ} \mathrm{C}\right)$ for $5 \mathrm{~d}$ prior to experiments. Prior to the experiment, the shrimp Penaeus monodon was collected from grow-out ponds or the sea near Chennai and maintained in $100 \mathrm{l}$ aquaria at a temperature of 27 to $30^{\circ} \mathrm{C}$ and salinity of 20 to $25 \mathrm{ppt}$. Five prawns/shrimp were randomly selected and screened for WSSV by PCR using primers designed by Yoganandhan et al. (2003). For the experiments, 5 from a group of 20 grossly healthy prawns/shrimps were randomly selected and screened for WSSV by PCR, and the remaining 15 were used in the experiments.
Preparation of viral inoculum. WSSV-infected Penaeus monodon ( $\mathrm{n}=200$ ) with prominent white spots were collected from shrimp farms located near Nellore, India. The hemolymph was drawn directly from the heart using sterile syringes followed by centrifugation at $3000 \times g$ for $20 \mathrm{~min}$ at $4^{\circ} \mathrm{C}$. The supernatant fluid was re-centrifuged at $8000 \times g$ for $30 \mathrm{~min}$ at $4^{\circ} \mathrm{C}$, and the final supernatant fluid was filtered through a $0.4 \mu \mathrm{m}$ filter. The filtrate was then stored at $-80^{\circ} \mathrm{C}$ for infectivity studies. The total protein in hemolymph was determined by the method of Lowry et al. (1951) and the presence of WSSV was confirmed by PCR amplification using primers designed by Yoganandhan et al. (2003).

Experimental challenge and sample collection. Prawns were challenged with WSSV filtrate $(300 \mu \mathrm{g}$ total protein per animal diluted to $50 \mu \mathrm{l}$ with NTE buffer $[0.2 \mathrm{M} \mathrm{NaCl}, 0.02 \mathrm{M}$ Tris HCL and $0.02 \mathrm{M}$ EDTA, pH 7.4]) by injection into muscle of the 2nd abdominal segment using $1 \mathrm{ml}$ insulin syringes and maintained (10 per group) in $100 \mathrm{l}$ fiberglass tanks at room temperature $\left(27\right.$ to $\left.30^{\circ} \mathrm{C}\right)$. Control prawns were injected with hemolymph from uninfected shrimp. Target organs were collected at different time intervals post injection (p.i.) and stored at $-80^{\circ} \mathrm{C}$ for RNA isolation.

Confirmation of WSSV infection. Template DNA for PCR tests was prepared from $100 \mathrm{mg}$ tissue samples from experimental shrimp, following the method described by Yoganandhan et al. (2003). Briefly, each tissue sample was homogenized with NTE and centrifuged at $3000 \times g$ at $4^{\circ} \mathrm{C}$, after which the supernatant fluid was placed into another centrifuge tube together with an appropriate amount of digestion buffer (100 mM NaCl, $10 \mathrm{mM}$ Tris HCl, 50 mM EDTA, 0.5\% SDS, $0.1 \mathrm{mg} \mathrm{ml}^{-1}$ Proteinase $\mathrm{K}, \mathrm{pH}$ 8.0). After incubation at $62^{\circ} \mathrm{C}$ for $2 \mathrm{~h}$, the digest was deproteinised by successive phenol/chloroform/iso-amyl alcohol extraction and recovered by ethanol precipitation and drying. The dried DNA pellet was resuspended in TE buffer and $50 \mu \mathrm{g}$ was used as template for each $\mathrm{PCR}$ reaction.

For PCR, primers were designed from the published sequence of the $28 \mathrm{kDa}$ envelope protein in the complete WSSV genome sequence (van Hulten et al. $2001 \mathrm{~b}$ ) in order to yield a $613 \mathrm{bp}$ amplicon (forward primer VP28-F 5'-ATGGATCTTTCTTTCACTCTTTC3' and reverse primer VP28-R 5'-CTCGGTCTCAGTGCCAG-3'). PCR products were analyzed by electrophoresis in $1 \%$ agarose gels stained with ethidium bromide $\left(0.5 \mu \mathrm{g} \mathrm{ml} \mathrm{m}^{-1}\right)$ and visualized by ultraviolet transillumination. The PCR protocol was 5 min denaturation at $95^{\circ} \mathrm{C}$ followed by 35 cycles consisting of $1 \mathrm{~min}$ each at 94,45 and $72^{\circ} \mathrm{C}$ followed by $10 \mathrm{~min}$ at $72^{\circ} \mathrm{C}$ (Yoganandhan et al. 2003). 
Table 1. Macrobrachium rosenbergii. Detection of white spot syndrome virus (WSSV) in different organs of WSSV-infected prawns at different time intervals (d post injection) using PCR, RT-PCR and Western blot techniques

\begin{tabular}{|c|c|c|c|c|c|c|c|c|c|c|c|c|c|c|c|c|c|c|c|c|c|c|}
\hline \multirow[t]{2}{*}{ Tissue } & \multicolumn{8}{|c|}{$\longrightarrow$ PCR $\longrightarrow$} & \multicolumn{7}{|c|}{$\longrightarrow$ RT-PCR } & \multicolumn{7}{|c|}{ Western blot } \\
\hline & $0 \mathrm{~d}$ & $1 \mathrm{~d}$ & $2 \mathrm{~d}$ & $3 d$ & $4 \mathrm{~d}$ & $5 \mathrm{~d}$ & $15 \mathrm{~d}$ & $90 \mathrm{~d}$ & $0 \mathrm{~d}$ & $1 \mathrm{~d}$ & $2 \mathrm{~d}$ & $3 d$ & $4 \mathrm{~d}$ & $5 \mathrm{~d}$ & $15 \mathrm{~d}$ & $0 \mathrm{~d}$ & $1 \mathrm{~d}$ & $2 \mathrm{~d}$ & $3 \mathrm{~d}$ & $4 \mathrm{~d}$ & $5 \mathrm{~d}$ & $15 \mathrm{~d}$ \\
\hline Hemolymph & - & - & + & + & + & + & + & + & - & - & + & - & - & - & - & - & - & - & - & - & - & - \\
\hline Gills & - & - & + & + & + & + & + & + & - & - & + & + & + & - & - & - & - & + & + & + & - & - \\
\hline Head soft & - & - & + & + & + & + & + & + & - & - & + & + & + & - & - & - & - & + & + & + & - & - \\
\hline Eyestalk & - & - & - & + & + & + & + & + & - & - & + & - & - & - & - & - & - & + & + & + & - & - \\
\hline
\end{tabular}

RNA extraction and RT-PCR analysis. For the isolation of total RNA, the hemolymph $(100 \mu \mathrm{l})$, gills tissue, eyestalks and head soft tissues (100 mg each) from Macrobrachium rosenbergii were homogenized in $1 \mathrm{ml}$ RNA isolation reagent TRIzol (Life Technologies) and then treated with RNase-free DNase I (Bangalore Genei) in order to remove any residual DNA. Firststrand cDNA synthesis was performed using the oligodT primer, and $2 \mu \mathrm{l}(\sim 1 \mu \mathrm{g})$ of the cDNA was subjected to PCR with the VP28 primer set (see above). The shrimp $\beta$-actin transcript was amplified using primers actin-F (5'-GAYGAYATGGAGAAGATCTGG-3') and actin-R (5'-CRGGGTACATGGTGGTRC C-3'), and served as an internal control for RNA quality and amplification efficiency. For both VP28 and $\beta$-actin, 30 cycles were run and the PCR products were analyzed by electrophoresis in $1 \%$ agarose gels stained with ethidium bromide and visualized by ultraviolet transillumination.

Western blot analysis. Western blot detection of VP28 in infected samples was conducted as described by Talbot et al. (1984). After separation on SDS-PAGE gel, proteins were transferred onto nitrocellulose membranes (Macherey-Nagel) that were subsequently treated overnight at $4{ }^{\circ} \mathrm{C}$ with blocking buffer followed by incubation with primary antiserum rabbit anti-rVP28 IgG (diluted to a ratio of 1:2500 in 1\% nonfat dry milk/phosphate-buffered saline) that was obtained in our previous study (Yoganandhan et al. 2004) for $3 \mathrm{~h}$. Subsequently, the membrane was incubated in ALPconjugated goat anti-rabbit IgG (Sigma) for $1 \mathrm{~h}$, and VP28 was detected using a substrate solution of 4-nitroblue tetrazolium chloride (NBT) and 5-bromo4-chloro-3-indolyl phosphate (BCIP) (Sigma).

Bioassay with Panaeus monodon. Panaeus monodon was maintained in 1001 fiberglass tanks at room temperature $\left(27\right.$ to $\left.30^{\circ} \mathrm{C}\right)$ with salinity that ranged between 20 and 25 ppt. Shrimp $(\mathrm{n}=10)$ were challenged by injection of a hemolymph preparation (300 $\mu \mathrm{g}$ total protein per individual, diluted to $50 \mu \mathrm{l}$ with NTE buffer) collected from WSSV-infected Macrobrachium rosenbergii at Day 90 p.i. into the muscle of the 2nd abdominal segment using a $1 \mathrm{ml}$ insulin syringe. After injection, shrimp were held in 1001 fiberglass tanks at room temperature $\left(27\right.$ to $\left.30^{\circ} \mathrm{C}\right)$. Control shrimp were injected with hemolymph from uninfected $M$. rosenbergii. Each trial was conducted in triplicate.

\section{RESULTS}

\section{Detection of WSSV by gross signs and PCR}

During the interval from 3 to $4 \mathrm{~d}$ p.i., WSSV-infected Macrobrachium rosenbergii showed signs of lethargy and stopped feeding, in contrast to control prawns, which behaved and fed normally. However, the WSSV-injected prawns suffered no mortality during this period and proceeded to recover without any further gross signs of disease or mortality over a period of $90 \mathrm{~d}$ p.i.. The results of PCR analysis of different organs obtained from WSSV-injected prawns are presented in Table 1. PCR analysis revealed the appearance of a prominent band of the PCR-amplified product of the VP28 gene (613 bp) at Day 2 p.i. in all organs except for the eyestalk. By Day 4 d p.i. this band was detected in all tested organs (Fig. 1) and product intensity was generally similar among samples. All tissues remained PCR positive for WSSV up to Day 90 p.i., the last day of PCR testing (Fig. 2), by which time amplicon band intensity had not diminished compared to the intensity at Day 4 p.i.

\section{RT-PCR analysis}

Messenger RNA of VP28 was clearly detected on Day 2 p.i. in all tissues tested, but it was not detected on Day 3 p.i. in the eyestalks and hemolymph (Table 1, Fig. 3A1,B1) or on Day 5 p.i. in head soft tissue or gill tissue (Fig. 3C1,D1). In contrast, host actin mRNA was detected in every sample (Fig. 3A2,B2,C2,D2). The purified WSSV-DNA positive control produced the expected amplicon, whereas negative controls with no template and with RNA extracts minus reverse transcriptase produced no amplicons. 

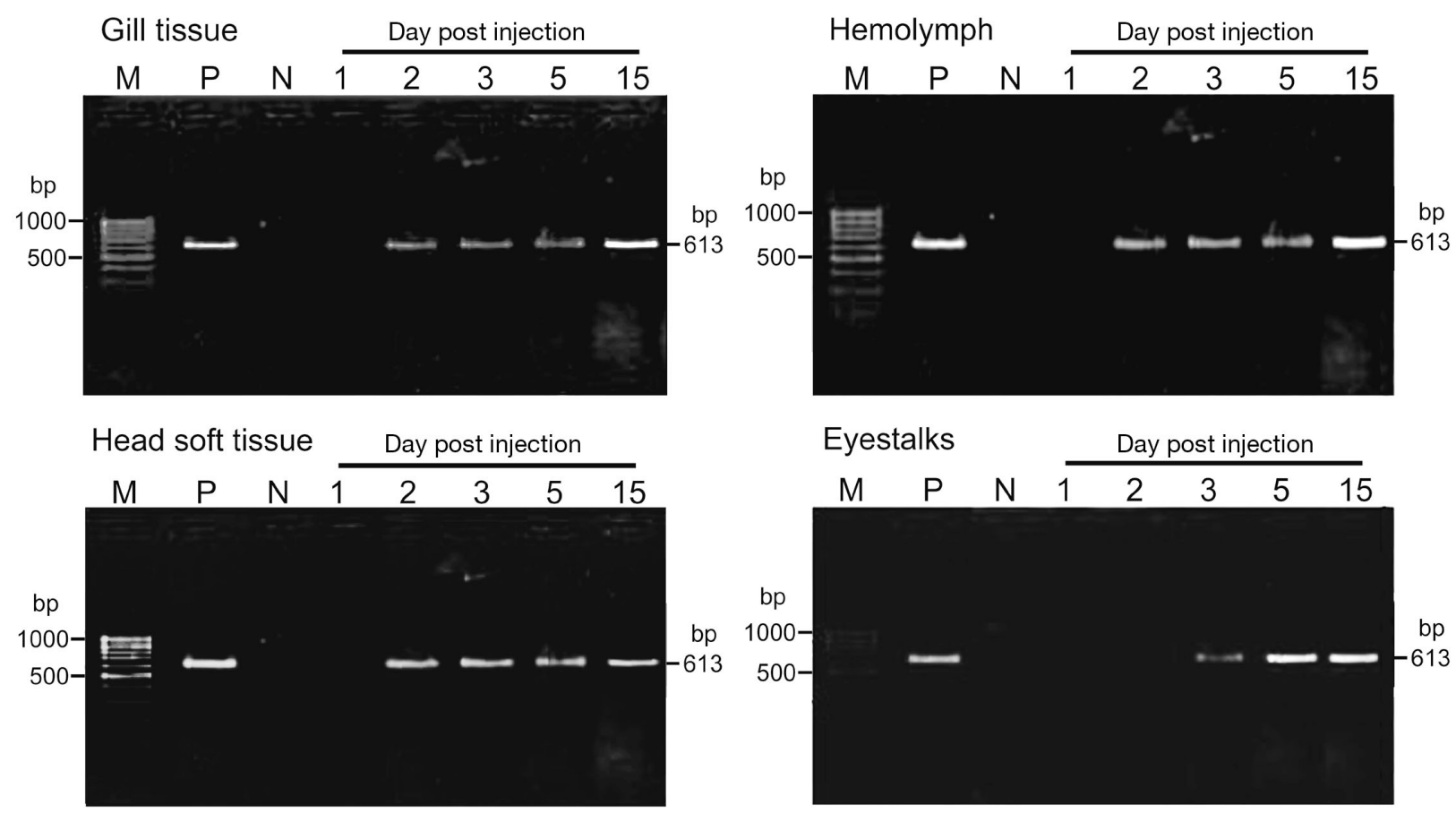

Fig. 1. Macrobrachium rosenbergii. PCR detection of WSSV-DNA in various tissues of WSSV-infected prawns at different days post injection. $\mathrm{M}=\mathrm{DNA}$ ladder marker, $\mathrm{P}=$ positive control, $\mathrm{N}=$ negative control

\section{Western blot analysis}

When equal amounts of total protein were subjected to $12 \%$ SDS-PAGE, Western blot analysis of viral proteins in the supernatant of infected tissue homogenates revealed differences in band intensity from different target organs. VP28 protein was lightly detected at Day 2 p.i. in head soft tissue, eyestalks and gills, but was no longer detectable from Day 5 p.i. onwards. This protein was not detected in hemolymph at any time up to the end of the testing period at Day 15 p.i. (Table 1, Fig. 3A3,B3,C3,D3).

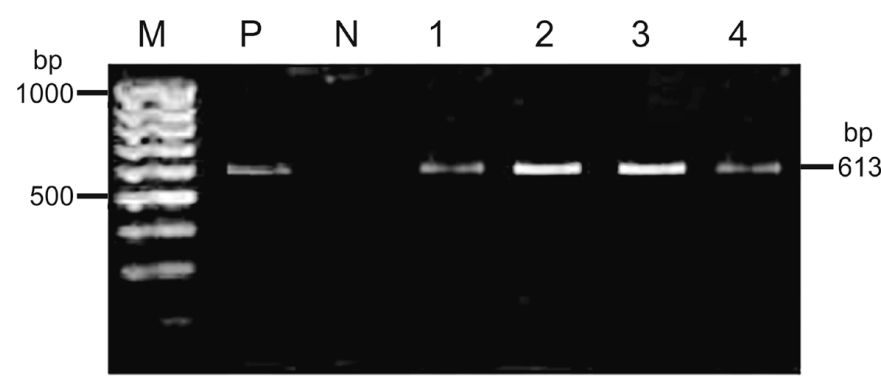

Fig. 2. Macrobrachium rosenbergii. PCR detection of WSSVDNA in 4 pooled tissue samples of WSSV-infected prawns at Day 90 post injection. $\mathrm{M}=\mathrm{DNA}$ ladder marker, $\mathrm{P}=$ positive control, $\mathrm{N}=$ negative control, $1=$ eyestalks, $2=$ gills, $3=$ head soft tissue, $4=$ hemolymph

\section{Bioassay}

Panaeus monodon was challenged with WSSV from Macrobrachium rosenbergii, and developed severe WSD when challenged with hemolymph from $M$. rosenbergii that were still positive for WSSV but negative for VP28 by PCR on Day 90 p.i.. WSD in P. monodon was confirmed by PCR (see 'Materials and methods') and histology (Lightner 1996).

\section{DISCUSSION}

Five major proteins from the WSSV virion with estimated sizes of $28,26,24,19$ and $15 \mathrm{kDa}$ have been reported. VP28 and VP19 are associated with the envelope, and others with the nucleocapsid (Nadala et al. 1997, van Hulten et al. 2000). Immunogold labeling has confirmed the presence of VP28 in the envelope (Zhang et al. 2002). The neutralization of VP28 by antiserum protects shrimp from WSD; thus, VP28 plays an important role in infection (van Hulten et al. 2001b, Syed Musthaq et al. 2006). For this reason, we considered VP28 to be a good target for the study of the interaction of WSSV with the challenged freshwater prawn Macrobrachium rosenbergii.

The fact that our WSSV-injected prawns exhibited lethargy and stopped feeding from Days 3 to 4 p.i. but 

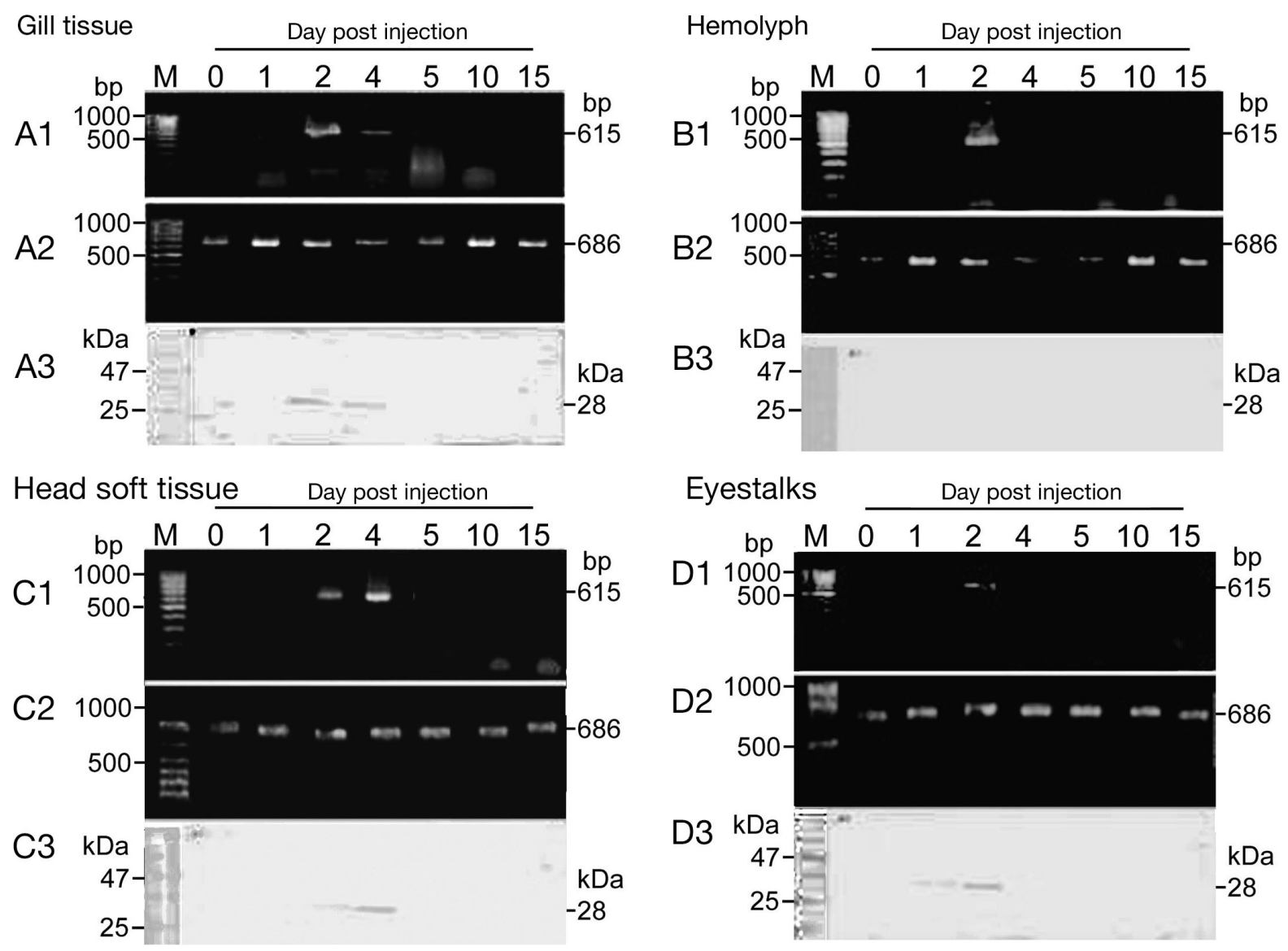

Fig. 3. Macrobrachium rosenbergii. Temporal analysis of VP28 gene expression in different organs of WSSV-infected prawns as determined by RT-PCR and Western blot analyses at different time intervals. (A1,B1,C1,D1) RT-PCR results for VP28; $(\mathrm{A} 2, \mathrm{~B} 2, \mathrm{C} 2, \mathrm{D} 2) \mathrm{RT}-\mathrm{PCR}$ results from the same samples for the $\beta$-actin gene; $(\mathrm{A} 3, \mathrm{~B} 3, \mathrm{C} 3, \mathrm{D} 3)$ Western blot results for protein extracts prepared from tissue samples parallel to those used for RNA extraction

later resumed normal behavior suggests that they suffered transient signs of early WSD and then recovered. This suggestion was supported by the RT-PCR and Western blot results, which demonstrated transient expression of the VP28 gene from Days 2 to 5 p.i. In contrast, the RT-PCR results were positive up to Day 4, probably owing to the higher sensitivity of the technique when compared to Western blot. The single-step PCR results of detection of the VP28 gene in WSSVDNA were positive from Day 2 to Day 90 p.i., at which time PCR testing was stopped. It is well-known that a single-step PCR positive test for WSSV indicates a relatively high level of WSSV infection (Peng et al. 1998b, Tsai et al. 1999). Although no VP28 messenger RNA could be detected at Day 90, the presence of viable WSSV was confirmed by bioassays with Penaeus monodon. Altogether, our results indicate that Macrobrachium rosenbergii can be infected with WSSV by injection and maintain a relatively high level of viral DNA presence without showing signs of WSD. The infection is persistent for up to $90 \mathrm{~d}$, and the infected prawns are potentially infectious to the shrimp P. monodon. Thus, as previously suggested by Flegel (2001), it would be best to refer to $M$. rosenbergii as being tolerant of rather than resistant to WSSV. This is in agreement with Peng et al. (1998a), who indicated that survivors of $M$. rosenbergii from larval challenge tests could remain infected for life without signs of disease. Sahul Hameed et al. (2000) also demonstrated that juvenile to adult stages of the freshwater prawn do not develop WSD when challenged with WSSV. In the present study, we show for the first time using bioassay that PCR-positive $M$. rosenbergii can cause WSD in $P$. monodon, and that this prawn presents a feasible threat as a potential carrier of WSSV, as proposed by Peng et al. (1998a).

The mechanism of tolerance to WSSV is not known. It has been reported not only in Macrobrachium rosenbergii but also in crabs (Supamattaya et al. 1998), Penaeus japonicus (Venegas et al. 2000) and even $P$. monodon under some circumstances (Tsai et al. 1999, Withyachumnarnkul 1999). The response of 
$P$. japonicus has been called 'quasi-immune' (Venegas et al. 2000). However, reference to 'immunity' may be misleading when one considers that an important feature of the tolerant state is the constant presence of infectious virus. It would be better to separate the issues of infection and disease and to ask why a viral infection sometimes causes disease and sometimes does not.

Our results may make a contribution towards answering this question. We have shown that the level of messenger RNA of the WSSV envelope protein VP28 initially increased after challenge but then became undetectable, despite the fact that Macrobrachium rosenbergii remained infected with WSSV as proven by single-step PCR assay and bioassay. In addition, using the same quantity of host DNA template, the PCR band intensity on Day 90 p.i. was not diminished when compared to that on Day 4 p.i., indicating that the target copy number of the VP28 gene (i.e. WSSV copy number) was not diminished. It is possible that other WSSV virion proteins could have shown the same expression profile as VP28. If so, this would suggest that there was a transient burst of virion protein production followed by a decrease that was not matched by viral DNA. Using immunohistochemistry with palaemonid shrimp tolerant to yellow head virus (YHV) infection, Longyant et al. (2005) recently reported that there was a very low signal for the viral coat protein gp116 but not for other virion proteins. Longyant et al. (2005) suggested that the low signal might have resulted from an alteration at the gp116 binding site for the gp116-specific monoclonal antibody, rather than from reduced gp116 production. However, these authors recently obtained identical results (unpubl.) with a polyclonal antibody of gp116 (P. Sithigorngul pers. comm.), suggesting instead that gp116 production is low when compared to that of other viral proteins. Should this be true for YHV and WSSV, low expression of some virion proteins relative to the quantity of viral nucleic acid would be linked to viral tolerance in both a DNA and RNA virus. This, in turn, would suggest the possibility of a general underlying process(es) associated with persistent infections in crustaceans. Whether these processes are part of a 'host immune response' governed by such factors as antiviral lysins and agglutinins that have been reported from invertebrates exposed to foreign proteins (Bang 1967) is open to speculation.

There must have been some VP28 expression that was below the detection level of our tests; this was evident from the fact that (1) hemolymph from our Day 90 Macrobrachium rosenbergii survivors was infectious to Penaeus monodon, and (2) VP28 was shown to be important in initiating WSSV infections in shrimp (van Hulten et al. 2001b). Although shrimp can be protected by feed- ing them with bacteria in which VP28 is expressed, this protection is not long-term, and nested PCR could be used to determine the persistence of WSSV after challenge in vaccinated shrimp (Witteveldt et al. 2004). Thus, the lack of disease following challenge with WSSV in tolerant, persistently infected crustaceans (e.g. M. rosenbergii) appears to differ markedly from the response of crustaceans that have been fed sub-unit proteins (e.g. $P$. monodon) (Namikoshi et al. 2004, Witteveldt et al. 2004). Both phenomena need to be more deeply examined.

\section{LITERATURE CITED}

Bachère E, Mialhe E, Noël D, Boulo V, Morvan A, Rodriguez J (1995) Knowledge and research prospects in marine mollusc and crustacean immunology. Aquaculture 132: 183-194

Bang FB (1967) Serological responses among invertebrates other than insects. Fed Proc 267:1680-1684

Cai S, Huang J, Wang C, Song X, Sun X, Yu J, Zhang Y, Yang C (1995) Epidermiological studies on the explosive epidermic disease of prawn in 1993-1994. J Fish China 19:112-117

Chang PS, Chen HC, Wand YC (1998) Detection of white spot syndrome associated baculovirus WSBV in experimentally infected wild shrimps, crabs and lobsters by in situ hybridization. Aquaculture 164:23-43

Chen LL, Lo CF, Chiu YL, Chang CF, Kou GH (2000). Natural and experimental infection of white spot syndrome virus (WSSV) in benthic larvae of mud crab Scylla serrata. Dis Aquat Org 40:157-161

Corbel V, Zuprizal Shi Z, Huang C, Arcier JM, Bonami JR (2001) Experimental infection of European crustaceans with white spot syndrome virus (WSSV). J Fish Dis 24: 377-382

Flegel TW (1997) Special tropic review: major viral disease of black tiger prawn Penaeus monodon in Thailand. World J Microbiol Biotechol 13:433-442

Flegel TW (2001) The shrimp response to viral pathogens. In: Browdy CL, Jory DE (eds) The new wave. Proceedings of the Special Session on Sustainable Shrimp Aquaculture, World Aquaculture 2001, Orlando. World Aquaculture Society, Boca Raton, FL, p 190-214

Huang C, Zhang X, Lin Q, Xu X, Hu Z, Hew CL (2002) Proteomic analysis of shrimp white spot syndrome viral proteins and characterization of a novel envelope protein VP466. Mol Cell Proteomics 1:223-231

Jiravanichpaisal P, Bangyeekhum E, Soderhall K, Soderhall I (2001) Experimentally infection of white spot syndrome virus in freshwater crayfish Pacifastacus leniusculus. Dis Aquat Org 47:151-157

Kanchanaphum P, Wongeteerasupsya C, Sitidilokratana N, Boonseng V, Panyim S, Tassnakajon A, Withyachumnarnkul B, Felegel TW (1998) Exprimental transmission of white spot syndrome virus WSSV from crabs to shrimp Penaeus monodon. Dis Aquat Org 34:1-7

Lightner DV (1996) A handbook of pathology and diagnostic procedures for diseases of penaeid shrimp. World Aquaculture Society, Baton Rouge, LA

Loh PC, Tapay LM, Lu Y, Nadala ECJ (1997) Viral pathogens of the penaeid shrimp. Adv Virus Res 48:263-312

Longyant S, Sithigorngul P, Chaivisuthangkura P, Rukpratanporn S, Sithigorngul W, Menasveta P (2005) Differences in susceptibility of palaemonid shrimp species to yellow head virus (YHV) infection. Dis Aquat Org 64:5-12 
Lowry OH, Rosebrough NJ, Farr AL, Randall RJ (1951) Protein measurement with the Folin Phenol reagent. J Biol Chem 193:265- 275

Mayo MA (2002) A summary of taxonomic changes recently approved by ICTV. Arch Virol 147:1655-1656

Nadala EC, Tapay LM, Cao S, Loh PC (1997) Detection of yellowhead virus and Chinese baculovirus in penaeid shrimp by the Western blot technique. J Virol Methods 69:39-44

Namikoshi A, Wu JL, Yamashita T, Nishizawa T, Nishioka T, Arimoto M, Muroga K (2004) Vaccination trials with Penaeus japonicus to induce resistance to white spot syndrome virus. Aquaculture 229:25-36

Nunan LM, Poulos BT, Lightner DV (1998) The detection of white spot syndrome virus (WSSV) and yellow head virus (YHV) in imported commodity shrimp aquaculture. Aquaculture 160:19-30

Peng SE, Lo CF, Ho CH, Chang CF, Kou GH (1998a) Detection of white spot baculovirus (WSBV) in giant freshwater prawn, Macrobrachium rosenbergii, using polymerase chain reaction. Aquaculture 164:253-262

Peng SE, Lo CF, Liu KF, Kou GH (1998b) The transition from pre-patent to patent infection of white spot syndrome virus (WSSV) in Penaeus monodon triggered by pereiopod excision. Fish Pathol 33:395-400

Sahul Hameed AS, Anilkumar M, Stephen Raj ML, Jayaraman K (1998) Studies on the pathogenicity of systemic ectodermal and mesodermal baculovirus (SEMBV) and its detection in shrimps by immunological methods. Aquaculture 160:31-45

Sahul Hameed AS, Xavier Charles M, Anilkumar M (2000) Tolerance of Macrobrachium rosenbergii to white spot syndrome virus. Aquaculture 183:207-213

Sahul Hameed AS, Yoganandhan K, Sathish S, Murugan V, Rasheed M, Jayaraman K (2001) Experimental pathogenicity of white spot syndrome virus (WSSV) in two freshwater crabs (Partelphusa hydrodomous and P. pulvinata). Aquaculture 201:179-186

Sahul Hameed AS, Murthi BLM, Rasheed M, Sathish S, Yoganandhan K, Murugan V, Jayaraman K (2002) An investigation of Artemia as a possible vector for white spot syndrome virus (WSSV) transmission to Penaeus indicus. Aquaculture 204:1-10

Sahul Hameed AS, Balasubramanian G, Syed Musthaq S, Yoganandhan K (2003) Experimental infection of twenty species of Indian marine crabs with white spot syndrome virus (WSSV). Dis Aquat Org 57:157-161

Supamattaya K, Hoffmann RW, Boonyaratpalin S, Kanchanaphum P (1998) Experimental transmission of white spot syndrome virus (WSSV) from black tiger shrimp Penaeus monodon to the sand crab Portunus palagicus, mud crab Scyla serrata and krill Acetes sp. Dis Aquat Org 32:79-85

Syed Musthaq S, Sudhakaran R, Ishaq Ahmed VP, Balasubramanian G, Sahul Hameed AS (2006) Tandem repetitive DNA sequences in Indian white spot syndrome virus (WSSV) isolates and suitability of VP28 gene to detect different repeat groups of WSSV. Aquaculture 256:34-41

Editorial responsibility: Timothy Flegel,

Bangkok, Thailand
Talbot PV, Knobler RL, Buchmeier M (1984) Western and dot immunoblotting analysis of viral antigens and antibodies: application to murine hepatitis virus. J Immunol Methods 73:177-188

Tsai MF, Kou GH, Liu HC, Liu KF and 5 others (1999) Longterm presence of white spot syndrome virus (WSSV) in a cultivated shrimp population without disease outbreaks. Dis Aquat Org 38:107-114

van Hulten MCW, Westenberg M, Goodall SD, Vlak JM (2000) Identification of two major virion protein genes of white spot syndrome virus of shrimp. Virology 266: $227-236$

van Hulten MCW, Witteveldt J, Peters S, Kloosterboer N and 5 others (2001a) The white spot syndrome virus DNA genome sequence. Virol 167:233-241

van Hulten MCW, Witteveldt J, Snippe M, Vlak JM (2001b) White spot syndrome virus envelope protein VP28 is involved in the systemic infection of shrimp. Virology 285: 228-233

Venegas CA, Nonaka L, Mushiake K, Nishizawa T, Muroga K (2000) Quasi-immune response of Penaeus japonicus to penaeid rod-shaped DNA virus (PRDV). Dis Aquat Org 42: $83-89$

Wang YC, Lo CF, Chang PS, Kou GH (1998) Experimental infection of white spot baculovirus in some cultured and wild decapods in Taiwan. Aquaculture 164: 221-231

Withyachumnarnkul B (1999) Results from black tiger shrimp Penaeus monodon culture ponds stocked with postlarvae PCR-positive or -negative for white-spot syndrome virus (WSSV). Dis Aquat Org 39:21-27

Witteveldt J, Vlak JM, van Hulten MCW (2004) Protection of Penaeus monodon against white spot syndrome virus using a WSSV subunit vaccine. Fish Shellfish Immunol 16: $571-579$

Wongteerasupaya C, Vickers JE, Sriuraitatana S, Nash and 6 others (1995) A non-occluded systemic baculovirus that occur in the cell of ectodermal and mesodermal origin and caused high mortality in the black tiger prawn Penaeus monodon. Dis Aquat Org 21:69-77

Yang F, He J, Lin X, Li X, Pan D, Zhang X, Xu X (2001) Complete genome sequence of the shrimp white spot bacilliform virus. J Virol 75:11811-11820

Yoganandhan K, Sathish S, Narayanan RB, Sahul Hameed AS (2003) Rapid non-enzymatic method of DNA extraction for PCR detection of white spot syndrome virus in shrimp. Aquac Res 34:1-5

Yoganandhan K, Syed Musthaq S, Narayanan RB, Sahul Hameed AS (2004) Production of polyclonal antiserum against recombinant VP28 protein and its application for the detection of white spot syndrome virus in crustaceans. J Fish Dis 27:517-522

Zhang X, Huang C, Xu X, Hew CL (2002) Identification and localization of a prawn white spot syndrome virus gene that encodes an envelope protein. J Gen Virol 83: 1063-1074

Submitted: June 13, 2005; Accepted: August 1, 2006

Proofs received from author(s): December 13, 2006 